\title{
Discussion on the Construction of Management Accounting Informatization under the Background of "Internet+"
}

\author{
MinSi Zhang ${ }^{\mathrm{a}}$, MeiLing Zhu ${ }^{\mathrm{b}}$ \\ School of Nanjing University of Science and Technology, Nanjing 210049, China \\ a1019321921@qq.com, bdameilingr@163.com
}

Keywords: Internet plus (+), management accounting information, suggestions.

\begin{abstract}
With the rapid development of information technology today, to create a new development ecology, "Internet + " gradually integrated into the various traditional vocation. Information just like a sharp sword break the existence of traditional accounting, letting accounting and information combined. Under this circumstance, the function of financial accounting gradually weakened, the development of management accounting information gradually strengthened. This paper elaborates the development of "Internet + " and the influence of "Internet + " on management accounting. At the same time, it also analyzes obstacles in the development of management accounting information and puts forward the corresponding suggestions.
\end{abstract}

\section{Introduction}

"Internet + " is not only the new trend of Internet development under Innovation 2.0, but also a platform that Internet promote economic and social development so as to promote the vitality of social economies, social reform for different industries, innovation and development. The informatization refers to the formation of the operating mode, which represent computer-based intelligent tools as the new productivity, which take information infrastructure as the basic operating environment, which look processing data and sharing information as final target. "Internet + " is the Internet and traditional industry in-depth integration, by communications, cloud computing and other emerging technologies, giving full play to the Internet in the allocation of social resources, optimizing the production factors, updating the social system, enhancing social creativity and productivity.

There are many features of "Internet +". The first one is cross-border integration. Plus"+" meaning cross-border, is integration of the Internet technology and social and economic sectors. The second one is reform and innovation. China's economic and social development has gradually transformed into innovation-driven development. The Internet provides everything with fresh blood. The third one is ecological protection. "Internet +" saves resources like wood and water. We need to develop our social economics, and pay attention to conserving ecological resources and reducing carbon emissions at the same time. The last one is unlimited connection. Aiming at connecting all relevant or unrelated things together is the target of "Internet +".

For the accounting industry, "Internet + " brings not only opportunities but also challenges. "Internet $+"$ provide accountant with efficient tools and platform to promote efficient work. However, the modern computerized information gradually replaced the traditional manual, traditional accountants may lose their jobs. And enterprises confidential information leakage is heavy. Under this circumstance, it is a popular tendency for us to integrate management accounting, business and information with innovation and reform.

\section{The impacts of "Internet +"on management accounting information}

\section{1 "Internet + " provides a platform for the development of management accounting information}

"Internet +" as hot words in 2016, representing the Internet technology is actively integrated into our economic society. Internet platform brings new economic growth spots for all kinds of traditional 
industries, the integration of traditional technology and emerging technology will also produce a series of innovation and development. Under the guidance of Internet, accounting field makes new requirements, such as refined management, data information, information sharing and knowledge structured, also comprehensive decision-making, which makes management accounting becoming more important in the field of accounting. At the same time, providing an effective platform for government management accounting departments of the public, online communication services, promote mode of further transformation of the accounting department, promote the development of management accounting information.

\section{2 "Internet +"establishes the data base of management accounting information}

Under the background of "Internet + ",enterprises can use the network platform combining data, letting the data structure of the enterprise more rich and comprehensive, breaking the "information island", improving sharing fast and accurate information between the various departments. The word management accounting informatization is based on the information of the entire enterprise, not only refers to the narrow sense of accounting information. Information exchange channels provided by "Internet + " help the management accounting catch systematic information, so that accountants analyze enterprise performance comprehensively. Besides, "Internet + " assist china market in reducing information asymmetry.

\section{3 "Internet +" supports the application of management accounting information}

"Internet +" supply applications for management accounting information. "Information" refers to computer-based intelligent tools as the representative of the new productive forces to provide and share data. To cost management, many companies have ERP, but did not realize that we can continue to optimize the utilization rate of raw materials when we use ERP. For example, after manufacturing company improved, material consumption can be timely calculated through the information system in the Internet, ERP can analyze the difference between actual cost and budget cost, reflecting the differences between changes in the cost of materials. Therefore, with the help of Internet technology, management accounting can achieve the unity of information and business.

\section{4 "Internet + " improves the efficiency of management accounting information work}

Internet technology can solve the problem of rapid transmission of electronic information between departments. Accounting information accuracy, timeliness, integration will be greatly improved. Hence, "Internet + " improves the efficiency of management accounting information work.

\section{Obstacles of management accounting information development under the background of "Internet +"}

There is a picture (Fig. 1) about four obstacles of management accounting information development.

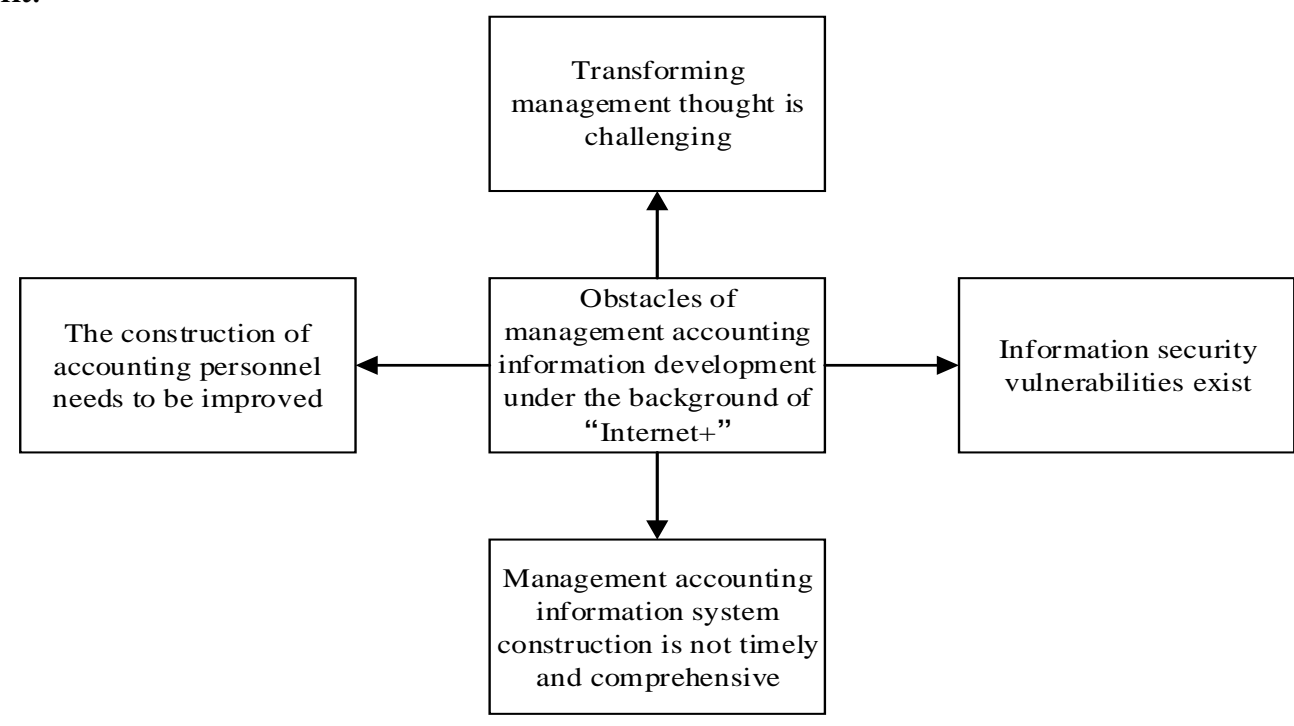

Fig. 1 Four obstacles of management accounting information development 


\subsection{Information security vulnerabilities exist}

"Internet + " give the community not only ease of obtaining information but insecurity of enterprise data. There are many insecure factors of enterprise data, from collection to analysis and calculation, facing hacker attack and system failure and other hidden dangers. The security of information data is the premise of the enterprise's operating profit, so how to protect the security of enterprise's information data is the key issue to be discussed. The security of information data is a prerequisite for business profitability, so the security of how to protect the information of the enterprise is the key issue that we should continue to explore.

\subsection{Transforming management thought is challenging}

Management accounting information is proposed in 2015, but for enterprises how to fully implement the management accounting information process is not overnight. From the traditional manual to current full-featured financial software, from the professional accounting staff to present information technology, management thought of accountant is transforming. Today's accounting staff need to use financial software, analyzing the financial situation and operating results of the enterprise by information technology. However, many old generation of accounting personnel, including CFO and other management personnel, misunderstand and exclude the process of management accounting informatization. For accounting practitioners, how to change thought of management accounting information needs appropriate measures.

3.3 Management accounting information system construction is not timely and comprehensive

Enterprises actively carries on the construction of management accounting information, but the information of the Internet is changing rapidly, the established accounting information system software cannot fully match the information development progress. Also it may be attacked by the network hackers and viruses. Therefore, the current management accounting information system needs to be improved.

\subsection{The construction of accounting personnel needs to be improved}

Management accounting has gradually changed from the traditional financial decision-making to management accounting information model, from manager to staff, aiming at achieving economic development goals. Therefore, enterprises need to establish efficient accounting personnel in line with the "Internet +", who owns innovative thinking, information technology and responsibility.

\section{Recommendations for management accounting information}

\subsection{Improving the accounting laws and regulations}

In order to protect the security of the Internet platform, our country needs to establish laws and regulations of Internet, china enterprises should build restriction of accounting, thus accounting field has its own rule to follow, the information shared in Internet platform will be more secure.

\subsection{Developing enterprise database security mechanism}

In order to prevent data leakage, enterprises should take measures to draw up its own database management authority through the password technology or firewall technology, not allowing illegal people to spy on the enterprise data. Besides, it is necessary for enterprises to establish input control system to minimize outside interference. Furthermore, corporates should build data monitoring system to pay attention to the safety and direction of the data.

\subsection{Speeding up the construction of accounting personnel}

In order to follow the trend of information development, corporates should adopt measures to construct accounting team, such as holding training sessions on IT and e-commerce at regular intervals. In addition, accountants need to be implanted thought that information is important so that staff all plant information and management accounting into their mind. 


\subsection{Intensify functions of accounting information system}

Under the background of "Internet +", the development of management accounting information is becoming main stream of our society, so corporates should realize the organic combination of accounting information and management. One of the most useful tool, accounting information system, is provided with functions of collecting, handing, storage and consultation. To be more specific, accounting information system provide the necessary information for enterprise planning and decision-making, and it can supervise, motivate, evaluate and reward the performance of employees, also it improves the efficiency of scarce resources. Enterprises need to improve its function to ensure the integrality of information and comprehensiveness of system itself.

\section{Conclusion}

Based on the above, according to the current development of management accounting information, it is of great significance to give some attention to the development of management accounting information under the background of "Internet +".In order to ensure the social and economic activities of sustainable development, make all walks of life have good prospects, China's enterprises need to actively develop the rules and regulations in line with the development trend of today's large data environment, and actively carry out the training of accounting personnel and improve the accounting information system so as to be able to get together to protect for China's economic construction.

\section{References}

[1] Yuanzhongyuan, huang, Research on the Application of Cloud Computing in the Management of Accounting Information under the background of Internet. Times Finance. (2017) No. 02, p. 179-180.

[2] Xin, leng, Discussion on the Construction of Accounting Information under the Background of Big Data. Journal of Chi feng University (Natural Science Edition). (2017) No. 02, p. 95-96.

[3] Lin, lin, Research on Accounting Security and Risk Control in Accounting Information Environment. SHANGYE JINGJI. (2017) No. 03, p.158-160. 